\title{
Efek Tryadic Communication Pura Samuantiga Dalam Pemujaan Tri Murti Di Bali
}

\author{
I Wayan Wirta ${ }^{1}$, Sintyananda Gayatri ${ }^{2}$ \\ ${ }^{12}$ Universitas Hindu Negeri I Gusti Bagus Sugriwa Denpasar \\ ${ }^{1}$ wayanwirta1@gmail.com, ${ }^{2}$ sintyananda.gayatri11@gmail.com
}

\begin{abstract}
There has been a conflict of understanding among Hindu religious groups, as a result of not adapting to the local cultural environment that has been considered well established. So as a consequence, there is a gap/conflict of understanding that has an impact on miscommunication. The concerns of various parties, especially among traditional Hindu figures as the "opinion leader" of Hindu communities in Bali with the concept of the teachings of "Tri Murti" insist on fortifying the influences of sampradaya teachings that are considered not in line with the tradition of "Dresta Bali". The effect of tryadic communication with the concept of Tri Murti teachings and the formation of pakraman villages/Balinese customary village is a strategic effort to anticipate, fortify and overcome conflicts between Hindu Religious groups, both at the pakraman village/customary village level and the family environment in Bali. The study used "dependency theory" from Ball-Rokeach and DeFlour. The method of data collection is participatory observation, in-depth interviews and literature studies. Data processing methods are carried out through processes : reduction, display and data verivikation. While the technique of determining informants is done purposive sampling.

As for the findings of this study that the name "Pura Kahyangan Tiga" does not describe the number of appropriate temples that should amount to three in each village pakraman/customary village, but the fact in the field is different, it could be that one village pakraman/customary village has two temples (if Pura Desa/Bale Agung and Pura Puseh combined in one area) and even the number of Pura Kahyangan Tiga can be more than three pieces (if Pura Dalem Setra more than one). Therefore, it needs to be reviewed, the naming of Pura Kahyangan Tiga which is not in accordance with the concept in question. Based on this description, several conclusions can be drawn, namely : 1) Tryadic communications is "a triangular communication" (samuantiga) which in its implementation has caused the effect of Tri Murti in Bali, both at the family level, pakraman village/customary village and more broadly at Pura Sad Kahyangan for all Hindu communities in Bali. 2) The effect of tryadic communications Pura Samuantiga on the level of pakraman village/customary village was built Pura Kahyangan Tiga, which consists of: Pura Desa/Bale Agung as a place of worship of Lord Brahma, Pura Puseh as a place of worship of Lord Visnu and Pura Dalem as a place of worship of Lord Siva, as well as a unifying medium for all Hindus in the territory/territorial wewidangan pakraman village/customary village. 3) The effect of tryadic communications Pura Samuantiga on the family sphere was built Palinggih Kamulan Rong Telu/Tiga, as a medium of worship Tri Murti and the ancestral spirit of the siddhadewata, as well as a unifying media in the family sphere.
\end{abstract}

Keywords : Tryadic Communication; Pura Samuantiga; The Worship Of Tri Murti 


\begin{abstract}
Abstrak
Telah terjadi pertentangan paham antarsekta keagamaan Hindu, sebagai akibat dari tidak beradaptasi dengan lingkungan budaya setempat yang selama ini sudah dianggap mapan. Maka sebagai konskuensinya, timbullah gap/pertentangan paham yang berdampak pada miskomunikasi. Kekawatiran berbagai pihak terutama di kalangan para tokoh tradisional Hindu selaku "opinion leader" masyarakat Hindu di Bali dengan konsep ajaran "Tri Murti" bersikeras membentengi pengaruh-pengaruh ajaran sampradaya yang dinilai tidak sejalan dengan tradisi "dresta Bali". Efek tryadic communication dengan konsep ajaran Tri Murti dan pembentukan desa pakraman/desa adat Bali merupakan upaya strategis untuk mengantisipasi, membentengi dan mengatasi pertentangan-pertentangan antarsekta keagamaan Hindu, baik pada tingkat desa pakraman/desa adat maupun lingkungan keluarga di Bali. Penelitian ini menggunakan dependency theory dari BallRokeach dan DeFlour. Metode pengumpulan datanya observasi partisipatif, wawancara mendalam dan studi pustaka. Metode pengolahan data dilakukan melalui proses : reduksi, display dan verivikasi data. Sedangkan teknik penentuan informan dilakukan secara purposive sampling.

Adapun temuan hasil penelitian ini bahwa nama "Pura Kahyangan Tiga" tidak menggambarkan jumlah pura yang sesuai yang seharusnya berjumlah tiga dalam setiap desa pakraman/desa adat, namun fakta di lapangan berbeda, bisa saja satu desa pakraman/desa adat memiliki dua buah pura (jika Pura Desa/Bale Agung dan Pura Puseh digabung dalam satu areal) dan bahkan jumlah Pura Kahyangan Tiga bisa lebih dari tiga buah (bila Pura Dalem Setranya lebih dari satu). Oleh karena itu perlu ditinjau kembali, pemberian nama Pura Kahyangan Tiga yang sudah tidak sesuai dengan konsep yang dimaksud. Berdasarkan uraian tersebut, dapat ditarik beberapa kesimpulan, yaitu : 1) Tryadic communications adalah komunikasi segi tiga (samuan tiga) yang dalam implementasinya telah menimbulkan efek pamujaan Tri Murti di Bali, baik pada tingkat keluarga, desa pakraman/desa adat maupun secara lebih luas pada Pura Sad Khyangan bagi seluruh masyarakat Hindu di Bali. 2) Efek tryadic communications Pura Samuantiga pada tataran desa pakraman/desa adat dibangun Pura Kahyangan Tiga, yang terdiri dari : Pura Desa/Bale Agung sebagai tempat pemujaan Dewa Brahma, Pura Puseh sebagai tempat pemujaan Dewa Wisnu dan Pura Dalem sebagai tempat pemujaan Dewa Siwa, sekaligus sebagai media pemersatu seluruh umat Hindu pada wilayah/wewidangan teritorial desa pakraman/desa adat. 3) Efek tryadic communications Pura Samuantiga pada lingkup keluarga dibangun Palinggih Kamulan Rong Telu/Tiga, sebagai media pemujaan Tri Murti dan roh leluhur yang sudah siddhadewata, sekaligus sebagai media pemersatu dalam lingkup keluarga.
\end{abstract}

Kata Kunci : Efek tryadic communication; Pura Samuantiga; Pemujaan Tri Murti

\title{
Pendahuluan
}

Efek tryadic communication menghasilkan kesefakatan bersama berupa "Keputusan Samuantiga" pada masa lampau di Bata Anyar (Bedulu), sebagai landasan filosofis penerapan konsep Tri Murti dan dan lahirnya desa pakraman/desa adat di Bali. Hasil Keputusan Samuantiga yang dipimpin seorang tokoh legendaris Mpu Kuturan (perwakilan sekta Buddha Mahayana) pada awal abad ke-11 Masehi, tepatnya tahun 1001 Masehi telah melahirkan monument media tradisional Hindu "Pura Samuantiga" yang hingga kini telah terimplementasi dengan baik, maka sebagai efeknya didirikanlah pura Kahyangan Tiga pada setiap desa pakraman/desa adat dan Kamulan Rong Telu pada setiap keluarga umat Hindu di Bali. Konsep ajaran Tri Murti dan keberadaan desa pakraman/desa adat telah menyatu dengan budaya "dresta Bali" yang pelaksanaannya 
sudah berjalan baik, namun demikian kedatangan sampradaya (aliran/sekta keagamaan) baru dengan style "Indianisasi" yang masih berlabel asli India menganggap dirinya sebagai sekta modern sehingga menimbulkan gap/pertentangan paham dengan tradisi Hindu yang selama ini sudah dianggap mapan. Kekawatiran berbagai pihak terutama di kalangan para tokoh tradisional Hindu selaku "opinion leader" masyarakat Hindu di Bali dengan konsep ajaran "Tri Murti" bersikeras membentengi pengaruh ajaran sampradaya yang dinilai tidak sejalan dengan tradisi "dresta Bali". Efek tryadic communication dengan konsep ajaran Tri Murti dan pembentukan desa pakraman/desa adat Bali merupakan upaya strategis untuk mengantisipasi, membentengi dan mengatasi pertentanganpertentangan antarsekta keagamaan Hindu di Bali. Efek tryadic communication hasil "Keputusan Samuantiga" sebagai salah satu bentuk komunikasi interpersonal (perwakilan antar tiga tokoh sekta keagamaan Hindu) yang telah melahirkan konsep ajaran Tri Murti, sebagai salah satu upaya mengantisipasi dan mengatasi timbulnya konflik sekta keagamaan Hindu, bahkan sebagai media penyatuan umat Hindu dan lahirnya desa pakraman/desa adat sebagai benteng yang tangguh pembertahanan masyarakat/umat Hindu di Bali.

Kecenderungan studi menunjukkan Pura Samuantiga belum banyak dikaji dari aspek komunkasi Hindu yang justru masih dianggap langka, belum banyak diketahui umat Hindu pada umumnya dan khususnya bagi umat Hindu di Bali. Penelitian ini dilihat dari sisi komunikasi Hindu, yakni dengan mengungkap efek tryadic communication (komunikasi segi tiga) sebagai salah satu bentuk komunikasi interpersonal Pura Samuantiga. Bedanya tulisan ini dengan yang lain, yang berbeda terletak pada perspektif dalam melihat phenomena efek tryadic communication Pura Samuantiga. Sedangkan dalam proses tryadic communication lebih menekankan hubungan antara seseorang selaku komunikator dengan dua orang selaku penerima pesan (komunikan). Bila dalam komunikasi interpersonal, komunikannya hanya satu orang saja maka akan berlangsung proses umpan balik atau arus pesannya dua arah (dyadic communication) yang cenderung bersifat dialogis. Sebaliknya bila komunikannya dua orang, maka akan berlangsung arus pesan tiga arah (tryadic communication) yang lebih dikenal sebagai "komunikasi segi tiga", yang dalam bahasa Bali disebut "samuan tiga" sebagaimana telah terjadi pada masa lampau sekitar awal abad ke-11 Masehi (tahun 1001 Masehi) di Bata Anyar (sekarang disebut : Desa Bedulu), di mana lokasi/tempat berlangsungnya proses komunikasi tiga arah perwakilan dari masing-masing tiga kelompok besar paksa, sampradaya atau sekta keagamaan Hindu (yaitu Siwa Siddhanta, Budha Mahayana dan Sadsekta Bali Aga) melakukan samua/sidang. Untuk mengenang kejadian penting tersebut, maka didirikanlah monument "Pura Samuantiga" sebagai tinggalan sejarah warisan budaya kerajaan Bali Kuno, yakni Kerajaan Bedahulu. Peristiwa monumental penting tersebut diabadikan dengan pendirian sebuah pura kahyangan jagat, pura yang sangat besar dan megah berlokasi di pusat pemerintahan kerajaan Bali kuno, yaitu kerajaan Bedahulu. Hal tersebut merupakan simbol identitas kebesaran kekuasaan kerajaan Bedahulu pada massa lampau. Objek material penelitian ini Pura Samuantiga, sedangkan objek formalnya efek tryadic communication yang dikaji sehubungan konteks penerapan konsep ajaran Tri Murti di Bali. Dengan demikian, hal terpenting dalam kajian ini adalah mengenai bagaimana hasil Keputusan Samuantiga diimplementasikan untuk mengantisipasi dan mengatasi terjadinya konflik-konflik sekta keagamaan yang sedang atau yang mungkin akan terjadi dirasakan telah meresahkan dan mengkawatirkan masyarakat Hindu di Bali. Uraian tersebut di atas, secara signifikan menunjukkan adanya hubungan erat antara tryadic communication Pura Samuantiga dan pemujaan Tri Murti di Bali.

Tujuan penelitian secara umum ingin mengkaji efek tryadic communication Pura Samuantiga, sedangkan tujuan khusus yang ingin dicapai dalam penelitian ini, adalah : 1) 
Untuk mengimplementasi pemahaman Konsepsi Keesaan Tuhan dalam implementasinya sebagai pemujaan Tri Murti Masyarakat Hindu di Bali; 2) untuk memahami efek tryadic communication Pura Samuantiga pada tataran desa adat/desa pakraman di Bali; 3) untuk memahami efek tryadic communication Pura Samuantiga dalam lingkup keluarga; Dalam pembahahan berikut dikaitkan dengan tiga efek komunikasi massa, yaitu : efek kognitif, afektif dan behavioral tryadic communication dengan penggunaan teori efek komunikasi massa (Dependency theory) dari Ball-Rokeach dan DeFlour. Teori ini dipakai membedah ketiga rumusan masalah. Adapun pesan penting yang ingin disampaikan dalam tulisan ini : "Tryadic communication Pura Samuantiga di masa lalu telah melahirkan konsep ajaran Tri Murti, namun demikian kini telah menimbulkan tanggapan pro dan kontra pemahaman serta implementasi konsep ajaran Tri Murti pada masyarakat Hindu di Bali, tataran desa adat dan dalam lingkup keluarga. Hal tersebut mendorong dilakukan studi ini untuk mengkaji "Efek Tradic Communication Pura Samuantiga dalam pemujaan Tri Murti di Bali" menjadi sebuah jurnal penelitian.

Adapun argument yang diajukan dalam penelitian ini, adalah sebagai berikut : Pertama, menumbuhkan kesadaran berdasarkan pemahaman teologis umat Hindu mengenai konsepsi Ke-Esaan Tuhan yang bersumber pada ajaran Weda, yang dapat diaplikasikan dalam kehidupan sehari-hari. Efek tryadic communication Pura Samuantiga pada tingkat pemahaman teologis umat Hindu sering menimbulkan pertentangan paham dengan penganut aliran/sekta keagamaan/sampradaya asing yang penampilannya yang sedikit nyeleneh (berbeda model) berkecenderungan "ke India-indiaan", serta tidak mau menyesuaikan diri dengan lingkungan budaya sekitarnya terutama pada moment ngayah bersama, justru sering menyalahkan praktek kegamaan Hindu yang selama ini sudah dianggap mapan oleh umat Hindu di Bali, sehingga terjadi pelampiasan prilaku yang tidak terkendali, didukung oleh rasa "ego sektoral" menimbulkan keresahan di kalangan masyarakat Hindu hingga terjadi benturan-benturan fisik sebagai salah satu efek pertentangan-pertentangan paham berupa miskomunikasi di kalangan umat Hindu di Bali. Kedua, Konsep ajaran Tri Murti sebagai media pemersatu dan sebagai solusi mengatasi konflik sekta keagamaan Hindu di Bali, baik pada seluruh masyarakat Hindu di Bali, tataran desa adat dan lingkup keluarga. Efek Tradic Communication Pura Samuantiga pada tataran desa adat/desa pakraman di Bali sangat penting dipahami oleh seluruh umat Hindu sehubungan eksistensi Pura Kahyangan Tiga (Pura Desa, Puseh dan Dalem) yang berada dalam lingkup satu wewidangan/wilayah territorial desa pakraman/desa adat. Setiap desa pakraman/desa adat wajib menyungsung Pura Kahyangan Tiga. Ketiga, menumbuhkan kesadaran bahwa pada hakikatnya keluarga bersumber dari satu ikatan darah yang secara geneologis berasal dari leluhur yang sama, dari kata "kaula warga". Kaula berarti pengabdian, dan warga maksudnya dalam satu ikatan (darah). Jadi kaula warga berarti pengabdian terhadap satu ikatan darah, karena pada hakikatnya berasal dari "getih abungbung" (berasal dari satu gumpalan darah dalam wadah satu bumbung yang terbuat dari satu ruas bambu). Pertentangan dalam keluarga dianggap suatu hal yang wajar, tidak perlu dipermasalahkan. Pada tingkat keluarga, efek tryadic communication Pura Samuantiga diimplementasikan dengan pendirian "Sanggah Kamulan Rong Telu/Tiga" sebagai media pemersatu dalam lingkup keluarga. Perbedaan pandangan terhadap kehadiran sampradaya baru telah dirasakan meresahkan umat Hindu terutama dalam lingkup desa pakraman/desa adat dan keluarga. Argument/hypotesis tersebut menunjukkan betapa pentingnya membangun komunikasi dalam menganalisis isu aliran/sekta keagamaan Hindu yang akan dibahas pada penelitian ini.

Pendirian Pura Samuantiga berdasarkan lontar Tatwa Siwa Purana dan prasasti yang tersimpan di Pura Sakenan, Desa Manukaya-Tampaksiring (berangka tahun 962 Masehi) yang dinyatakan bahwa Pura Samuantiga dibangun sejaman dengan pendirian 
Pura Tirtha Empul (sekitar akhir abad X Masehi) oleh Raja Candrabayasangka (yang dimaksud : Candrabayasingha Warmadewa) yang memerintah sekitar tahun 942-989 Masehi. Pura Samuantiga berlokasi pada daerah yang sangat strategis berada di tengahtengah (sentralnya) Pulau Bali, namun difungsikannya sebagai lokasi "pesamuan" (sidang besar) berlangsung saat kekuasaan raja suami istri (Dharma Udayana Warmadewa dan Gunapriya Dharmapatni/Mahendradata), yang memiliki gagasan bagaimana upaya mengatasi konflik sekta keagamaan Hindu tahun 1001 Masehi di wewidangan Bata Anyar. Pura Samuantiga berada pada titik koordinat $8^{0} 31^{\prime} 4^{\prime \prime}$ lintang selatan dan $115^{0} 17$ '56,6" bujur timur, dengan ketinggian sekitar 90 meter dari permukaan laut (Oka Astawa, dkk., 2006, p. 10). Secara topografis, Pura Samuantiga terletak pada struktur tanah dengan ketinggian di bagian utara dan selatan agak tinggi, sedangkan pada bagian tengah terdapat pelataran yang yang agak datar membentang dari arah barat pura (labak) ke palataran pura, sampai pura Tegal Panangsaran dan Pura Dalem Puri, serta areal persawahan yang berada di sebelah timur pura (Purana Pura Samuantiga, 2016). Keberadaan Pura Samuantiga dengan lingkungan alam sekitarnya memperlihatkan suasana alam yang natural, dikelilingi berbagai pepohonan yang rindang. Lokasi Pura Samuantiga dengan sangat mudah dapat dijangkau dari segala penjuru arah, yaitu dari jalur arah barat (Kodya Denpasar), dari jalur selatan (Kabupaten Gianyar) dan juga dari jalur utara (Kecamatan Tampaksiring). Setelah sampai pada catus pata (perempatan) Desa Bedulu, pencarian mengarah ke arah timur kurang lebih 400 meter, maka akan sampai pada lokasi yang dituju. Pura Samuantiga yang terletak di Desa Bedulu, Kecamatan Blahbatuh, Kabupaten Daerah Tingkat II Gianyar, Provinsi Bali merupakan pura tinggalan sejarah kerajaan Bali Kuno yakni Kerajaan Bedulu sekitar awal abad ke-11 Masehi (tahun 1001 Masehi) dengan wewidangan/wilayah Bata Anyar. Di antara ketiga akses yang dilalui, akses arah Tampaksiring-Gianyar berpeluang besar bersentuhan dengan penduduk daerah-daerah hunian Bali aga/Bali mula, yang berlokasi di sekitar daerah Kabupaten Buleleng, Bangli dan Karangasem, diantaranya : Desa Cempaga, Sidatapa, Tigawasa, Pedawa, Sembiran, Kintamani, Trunyan, Tianyar, Tenganan dan lain sebagainya sehingga memungkinkan terjalin hubungan harmonis dengan masyarakat desa-desa tradisional Bali Aga dengan pusat pemerintahan kerajaan Bali kuno, yakni kerajaan Bedahulu di masa silam. Pemberian nama Pura Samuantiga didasarkan atas petikan Lontar Dewa Purana Bangsul (Oka Astawa, 2006, p. 21) yang menyebutkan adanya peristiwa yang sangat penting yang pernah terjadi sehubungan dengan masalah konflik sekta keagamaan/sampradaya yang dapat diselesaikan (dipecahkan bersama) melalui

samиa" (musyawarah) yang ditunjukkan melalui petikan lontar, dengan perkataan "ika maka cihna mwah genah" sesuai kutipan berikut ini : “....ri masa ika hana malih kahyangan kang maka ngaran kahyangan Samuantiga, ika maka cihna mwah genah irakang para dewata, bhatara-bhatari mwah kang para rsi ika makabehan paum duking masa ika, kang ingaran Pura Samuantiga ri mangke.

Dengan demikian, "samua" (musyawarah) yang dihadiri oleh para tokoh perwakilan dari tiga sekta besar keagamaan Hindu, yaitu Sekta Siwa Siddhanta, Budha Mahayana dan Sadsekta Bali Aga yang dipimpin langsung oleh Mpu Kuturan (perwakilan dari Sekta Budha Mahayana), sehingga berlangsunglah proses komunikasi interpersonal "tryadic communication" (komunikasi segi tiga) sebagai acuan penerapan konsep ajaran Tri Murti di Bali.

Pura Samuantiga diempon oleh lima desa pakraman/desa adat yang berasal dari dua kecamatan yang berbeda, yaitu Kecamatan Blahbatuh dan Kecamatan Sukawati sebagai suatu yang unik yang selama ini jarang ditemui di Bali, yang secara keseluruhan pangemponnya berjumlah lima desa adat/desa pakraman, yang terdiri dari 12 banjar adat, yaitu : 1) Banjar Taman, 2) Banjar Pekandelan, 3) Banjar Wanayu, 4) Banjar Mas, 5) Bajar 
Tengah, 6) Bajar Tengkulak, 7) Banjar Margabingung, 8) Banjar Lebah, 9) Banjar Batulumbang, 10) Banjar Tengkulak Kaja Kangin, 11) Banjar Tengkulak Kaja Kauh, dan 12) Banjar Tengkulak Tengah. Untuk memudahkan pengaturan jumlah pangempon banjar adat yang sangat besar dan pelaksanaan upacara yajña/ritual yang begitu kompleks dengan biaya yang cukup besar, maka dibuatkanlah "Paruman Pura Samuantiga" sebagai perwakilan dari masing-masing banjar adat pangempon Pura Samuantiga yang didukung sepenuhnya oleh pangayah khusus permas dan parekan mengacu pada konsep teori trias politika, yang terdiri dari : aspek yudikatif, ekskutif dan legislatif yang dirancang dalam pembentukan kepanitian setiap pelaksanaan karya padudusan, baik pada Karya Padudusan Alit (tahun Masehi ganjil) maupun Karya Padudusan Agung (tahun Masehi ganjil) di Pura Samuantiga.

Fenomena menarik dari paparan tersebut di atas, bahwa Pura Samuantiga adalah pura tinggalan sejarah kerajaan Bali Kuno yang berlokasi di wewidangan Bata Anyar (sekarang : Desa Bedulu) berlokasi pada daerah yang sangat strategis, yakni berada di tengah-tengah Pulau Bali (sebagai sentralnya) Provinsi Bali, serta memiliki karakteristik pangempon pura yang unik (percampuran antara masyarakat Bali Aga/Bali mula/Bali asli dan Bali Apanaga/Bali pendatang/pengikut ekspedisi Majapahit yang datang pada periode belakangan (menjelang runtuhnya Majapahit). Pura Samuantiga diempon oleh dua kecamatan yang berbeda yaitu Kecamatan Bedulu dan Kecamatan Sukawati, serta memiliki pangayah khusus yang tidak ditemui pada pura lainnya di Bali, sebagai pangayah yang sangat diandalkan yaitu "Permas dan Parekan" yang yang berperan penting dan ngayah secara tulus ikhlas, serta bertanggungjawab penuh atas pelaksanaan yajña/ritual di Pura Samuantiga. Sekalipun Pura Samuantiga diempon oleh 12 banjar adat yang jumlah secara keseluruhan $1930 \mathrm{KK}$ (Kepala Keluarga) yang terdiri dari : $745 \mathrm{KK}$ pangarep dan $1.185 \mathrm{KK}$ pangempi tergolong dalam jumlah pangempon yang sangat besar dan kompleks, namun dalam prakteknya selama ngayah yang dimulai dari sejak persiapan, pelaksanaan hingga nyineb (penutup) yajña/ritual di Pura Samuantiga semuanya ditangani dengan penuh tanggung jawab oleh Permas dan Parekan (Wirta, 2019).

\section{Metode}

Adapun objek material penelitian ini adalah Pura Samuantiga, sedangkan objek formalnya adalah efek tryadic communication. Bagaimana melihat Pura Samuantiga dari perspertif efek tryadic communication yang telah terimplementasi dalam kehidupan masyarakat Hindu di Bali, pada tataran desa pakraman/desa adat dan lingkup keluarga. Jadi kajian tryadic communication Pura Samuantiga dari perspektip ilmu komunikasi yang kajiannya didasarkan atas jumlah komunikan melalui hubungan kedekatan secara personal, yang masih tergolong dalam bentuk komunikasi interpersonal (bukan komunikasi kelompok). Hal tersebut dapat diketahui didasarkan atas hubungan kedekatan antara komunikator (Mpu Kuturan) yang memberi pemahaman secara holistik dan logis kepada para peserta sidang dengan menawarkan solusi konsep ajaran Tri Murti, sehingga usul/pendapatnya dapat diterima oleh semua kalangan, terutama pihak-pihak sekta lainnya, seperti : sekta Siwa Sidhanta dan Sadsekta Bali Aga. Singkatnya, kajian mencakup objek material "Pura Samuantiga" dilihat dari perspektif "efek tryadic communication" (sebagai objek formal), yang merupakan bagian dari salah satu dari bentuk komunikasi interpersonal.

Data yang dibutuhkan dalam penelitian ini adalah data kualitatif yang terfokus pada kajian-kajian secara deskriptif. Desain penelitiannya deskriptif kualitatif. Data yang diperoleh dikelompoknya menjadi tiga kategori efek, yaitu : efek kognitif (perubahan pengetahuan), efek afektif (perubahan sikap) dan efek behavioral (perubahan prilaku). Dengan demikian tujuan penelitian diharapkan dapat tercapai melalui penggunaan teori 
efek komunikasi massa (dependency theory dari Ball-Rokeach dan DeFleur). Jenis data dalam penelitian ini adalah data primer yang diperoleh secara langsung di lapangan dengan penggunaan teknik pengumpulan data melalui observasi partisipatif, yang dilakukan dengan melakukan pengamatan dan peneliti ikut berperanserta aktif dalam berbagai kegiatan dan juga melalui wawancara mendalam terhadap informan dengan mewawancarai informan yang telah ditentukan dan dengan mencari, mengolah data melalui penelusuran facebook pada konten-konten media sosial video atau youTube yang relevan di mana temuan data tersebut diolah sendiri sebagai data primer, serta jenis data skunder yang diperoleh melalui kutipan-kutipan sumber yang telah tersedia dengan penggunaan metode pengumpulan data dengan studi pustaka. Dengan demikian data primer dan data skunder sangat dibutuhkan sebagai bahan analisis dalam penelitian ini.

Teknik penentuan informan dilakukan secara purposive sampling, di mana peneliti telah menentukan informan berdasarkan kriteria yag telah ditetapkan sesuai pengetahuan yang dibutuhkan. Sumber informasi dalam penelitian ini adalah berbagai kegiatan atau aktivitas yang berhubungan dengan efek tryadic communication Pura Samuantiga dengan mewancarai informan yang dipandang memiliki pengetahuan memadai dibutuhkan penelitian ini dan juga dengan menelusuri sumber-sumber literatur yang tersedia. Metode observasi diakukan melalui pengamatan yang dimulai dari sejak persiapan upacara yajña/ritual saat wali/piodalan Pura Kahyangan Tiga dan piodalan di sanggah atau merajan dalam lingkup keluarga. Dengan demikian, penentuan teknik purposive sampling dilakukan melalui penentuan informan yang dipandang memiliki kualifikasi pengetahuan yang memadai yang dibutuhkan dalam penelitian.

Metode pengumpulan data memakai teknik observasi partisipatif, wawancara mendalam dan studi pustaka. Metode observasi dilakukan dengan pengamatan pelaksanaan yajña atau ritual yang didokumentasikan melalui foto dengan penggunaan HP. Wawancara mendalam dilakukan peneliti terhadap nara sumber yang dipandang kompeten (direkam dengan HP) yang dianggap memiliki keahlian memadai yang dibutuhkan dalam penelitian ini dengan cara mewawancarai pemangku ageng Pura Samuantiga dan beberapa tokoh-tokoh Hindu lainnya. Penelusuran informasi dapat juga dilakukan untuk menemukan data dengan penggunaan tekhnologi informasi canggih melalui facebook pada konten video dan youTube dalam media sosial (medsos). Data yang ditemukan sendiri secara langsung melalui konten-konten tersebut dan diolah sebagai data tergolong dalam data primer. Penggunaan metode studi pustaka (library research) dilakukan melalui membaca buku-buku yang relevan untuk memperoleh informasi sehubungan masalah yang akan dikaji dengan menelusuri berbagai literatur, berupa : mengakses jurnal hasil penelitian, membaca buku, karya ilmiah skripsi, tesis, disertasi termasuk mengkaji lontar dan purana yang terkait dengan Pura Samuantiga. Dengan demikian metode pengumpulan data dalam penelitian ini dilakukan dengan penggunaan teknik observasi, wawancara dan studi Pustaka.

Metode pengolahan data dilakukan melalui proses : reduksi, display dan verivikasi data. Dalam analisis data, tiga alur kegiatan terjadi secara bersamaan melalui reduksi, display dan verifikasi data (Miles \& Hubermann, 1992). Reduksi data adalah langkah pertama dalam kegiatan pengolahan data, sejak dilakukan proses pemilihan, penyederhanaan, pengabstrakan dan transformasi data kasar dari catatan-catatan tertulis di lapangan yang berlangsung secara terus-menerus dimulai sejak awal penelitian. Proses reduksi data, dapat dilakukan dengan membuat ringkasan, mengkoding, menelusuri tema dan menulis memo. Sedangkan display data, adalah sekumpulan informasi yang telah tersusun, sehingga memungkinan untuk penarikan kesimpulan. Sedangkan verifikasi data adalah langkah terakhir dalam proses pengolahan data dengan penarikan kesimpulan yang diarahkan untuk menjawab rumusan masalah/argumentasi dalam penelitian. Berdasarkan 
uraian tersebut di atas, pengolahan data dalam penelitian ini dilakukan secara reduksi, display dan memverivikasi data.

\section{Hasil dan Pembahasan}

Perkataan Pura Samuantiga terdiri dari kata "pura" berasal dari akar kata "pur" (Bahasa Sanskerta) berarti tembok berbenteng, maksudnya tempat suci sebagai media pemujaan Tuhan/Ida Sanghyang Widhi Wasa. Kata Samuantiga secara etimologi merupakan bentukan dari kata "samuhan" berasal dari kata dasar "samuh", mendapat akhiran an. Samuhan berarti : pertemuan, musyawarah, rapat dan kata samuhan mengalami proses peluluhan bunyi $h$, sehingga menjadi "samuan", dan kata "tiga" menunjuk pada bilangan tiga. Apabila perkataan "samuan" ditambahkan awalan pa menjadi "pasamuan" mengandung arti pertemuan dan kata tiga menunjukkan unsur bilangan. Dengan demikian pasamuantiga dapat dimaknai pertemuan tiga unsur, maksudnya pertemuan yang dihadiri oleh tiga pihak atau tiga kelompok sekta keagamaan Hindu, yang sering disebut "pertemuan segi tiga" atau yang semacam itu (Oka Astawa, 2006). Soebandi (2003) memaknai "samuantiga" sebagai pertemuan segi tiga, yakni pertemuan yang dihadiri oleh tiga unsur kekuatan berlangsung secara personal yang mewakili kepentingan kelompok. Pertemuan yang dimaksud adalah bertemunya tiga kelompok besar sampradaya/aliran kepercayaan/sekta keagamaan Hindu, guna penyatuan visi mengenai sistem kepercayaan di Bali (Profil Pura Kahyangan Jagat di Bali, 2012). Perkataan "samиa" diidentikkan dengan perkataan "samuha" berarti musyawarah (Kamus Bali-Indonesia Beraksara Bali dan Latin, 2013). Perkataan samua bermakna sama dengan perkataan "sangkep/parum" (Kamus Bali-Indonesia, 1996). Uraian tersebut menunjukkan bahwa perkataan Samuantiga berasal dari kata dasar "samua". Dengan demikian Pura Samuantiga adalah tempat suci yang berkaitan erat dengan peristiwa penting "proses komunikasi segi tiga" antartokoh sekta keagamaan Hindu sebagai pura peninggalan sejarah kerajaan Bali Kuno yang berlokasi di Desa Bedulu (wewidangan Bata Anyar) yang kini bernama Desa Bedulu. Kerajaan Bedahulu diperkirakan berlokasi tidak terlalu jauh dari Pura Samuantiga, diperkirakan sekitar 700 meter berada di sebelah barat daya dari lokasi Pura Samuantiga. Lokasi yang dimaksud adalah Pura Pengastulan dan Pura Jero Agung. Menurut informan (informan 1 : Rai, 77 tahun), perkataan pengastulan dimaknai "pengastitian" yang diperkirakan sebagai tempat pemujaan yakni "pamerajannya" kerajaan Bedahulu. Persis di sebelah barat dari lokasi Pura Pengastulan (masih dalam satu kompleks) terdapat sebuah pura yaitu Pura Jero Agung, yang diperkirakan sebagai lokasi istana kerajaan Bedahulu.

Pertemuan "segi tiga" sekta keagamaan Hindu, jika dilihat dalam perspektif ilmu komunikasi didasarkan atas jumlah komunikannya tergolong dalam bentuk komunikasi interpersonal (bukan komunikasi kelompok), di mana komunikannya hanya berjumlah dua orang. Maksudnya ada tiga orang yang terlibat langsung dalam proses komunikasi, memiliki hubungan kedekatan yang bersifat personal, yang dalam studi ini dinamai "tryadic communication", yang telah menghasilkan sebuah keputusan penting di masa silam, yaitu Keputusan Samuantiga, yang telah diabadikan dengan pendirian sebuah pura, yaitu : "Pura Samuantiga".

Pemujaan Tri Murti adalah konsep pemujaan Tuhan Yang Maha Esa/Ida Sanghyang Widhi Wasa dalam manifestasiNya sebagai Dewa Tri Murti, yang terdiri dari : 1) Dewa Brahma adalah manifestasi Tuhan sebagai pencipta seluruh alam semesta beserta isinya, yang disimbolkan dengan pranawa aksara "A/Ang", 2) Dewa Wisnu adalah manifestasi Tuhan sebagai pemelihara seluruh alam semesta beserta isinya, yang disimbolkan dengan pranawa aksara "U/Ung", dan 3) Dewa Siwa adalah manifestasi Tuhan sebagai pemralina seluruh alam semesta beserta isinya dengan pranawa aksaranya 
"M/Mang". Ketiga aksara suci tersebut (A, U, M) bila digabung menjadi "AUM", dan disandhikan menjadi "OM" adalah simbol Keesaan Tuhan. Jadi Tuhan yang satu (tunggal) dimanifestasikan menjadi tiga perwujudan/"murti", sehingga ketiga-tiganya disebut Tri Murti (Tri Tunggal), yang dalam ranah kajian filsafat dikatakan "Tuhan itu satu dalam tiga wujud atau sebaliknya tiga hakikat namun masih tetap dalam satu esensial". Sesungguhnya Tuhan itu satu adanya. Hal tersebut dimungkinkan karena keterbatasan kemampuan manusia dalam memahami eksistensi Tuhan Yang Mahaesa/Ida Sanghyang Widhi Wasa yang sesungguhnya bersifat transcendental dan yang serba mahasempurna. Sebaliknya kemampuan manusia yang serba terbatas, memungkinkan menimbulkan banyak persepsi dan bahkan pemberian banyak nama. Untuk mengimplementasikan hal tersebut, maka di Bali dibuatkan Pura Kahyangan Tiga sebagai media pemujaan Tuhan, baik dalam tataran wadah desa pakraman/desa adat maupun Kamulan Rong Telu dalam setiap keluarga (termasuk keluarga besar/dadya/kawitan). Desa adat adalah desa tradisional yang bersifat otonum, yang berkaitan erat dengan keberadaan Pura Kahyangan Tiga dan Pura Kahyangan Desa. Desa Pakraman, kini lebih dikenal dengan "Desa Adat". Perkataan desa adat terdiri dari kata desa dan adat. Bali merupakan daerah yang sangat unik, yang memiliki dua jenis desa, yaitu desa dinas adalah desa yang mengurus urusan administratif yang berhubungan erat dengan urusan pemerintahan, sedangkan desa adat adalah desa tradisional yang bersifat otonum berkaitan erat dengan keberadaan Pura Kahyangan Tiga, yang terdiri dari : Pura Desa/Bale Agung, Pura Puseh dan Pura Dalem, serta pura kahyangan desa. Desa pakraman/pakraman adat dipimpin oleh bendesa adat. Jadi desa adat adalah desa tradisional otonum yang mngatur kehidupan masyarakat Hindu di Bali sehubungan dengan penyungsungan Pura Kahyangan Tiga, selain adanya desa dinas. Efek Kognitif Tryadic Communication Pura Samuantiga adalah efek yang mencakup pengetahuan tentang konsep pemujaan Tri Murti, yaitu apa yang diketahui sehubungan dengan konsep ajaran Tri Murti, yang uraiannya mencakup tiga hal, yaitu : pemahaman teologis konsepsi Keesaan Tuhan dalam Veda, pemujaan Tri Murti dalam tataran desa pakraman/desa adat dan pemujaan Tri Murti dalam lingkup keluarga.

\section{Pemahaman Teologis Konsepsi Keesaan Tuhan (konsep ajaran Veda) yang Diimplementasikan Dalam Pemujaan Tri Murti Masyarakat Hindu di Bali}

Pemahaman teologis umat Hindu di Bali tentang ajaran Tri Murti yang mengacu pada konsep ajaran Veda sebagai upaya strategis pencegahan secara preventif dan mengatasi akan terjadinya konflik sekta keagamaan Hindu/sampradaya yang belakangan ini marak di Bali. Konsep ajaran tersebut tertera pada tabel berikut :

Tabel 1 : Konsepsi Keesaan Tuhan dalam Berbagai Sumber

\begin{tabular}{|c|c|c|c|}
\hline $\begin{array}{c}\text { Petikan Kalimat } \\
(\text { Sesanti })\end{array}$ & Arti & Orientasi Konsep & Sumber \\
\hline $\begin{array}{l}\text { Ekam Sat viprah } \\
\text { bahudha vadanti, } \\
\text { Agnim, Yaman } \\
\text { matariswanam } \\
\text { ahuh }\end{array}$ & $\begin{array}{lr}\begin{array}{l}\text { Tuhan itu satu, } \\
\text { namun } \\
\text { bijaksana }\end{array} \\
\text { menyebut dengan } \\
\text { banyak nama, } \\
\text { seperti : Agni, } \\
\text { Yama, Matariswa } \\
\text { dan } \\
\text { sebagainya }\end{array}$ & $\begin{array}{l}\text { Tuhan } \\
\text { sesungguhnya satu, } \\
\text { namun orang } \\
\text { bijaksana memberi } \\
\text { gelar bermacam- } \\
\text { macam, seperti : } \\
\text { Agni, Yama, } \\
\text { Matariswa, dll. }\end{array}$ & Rg Veda I.164.46 \\
\hline
\end{tabular}




\begin{tabular}{|l|l|l|l|}
\hline $\begin{array}{l}\text { Eko narayana } \\
\text { nadwityo'sti kascit }\end{array}$ & $\begin{array}{l}\text { Tuhan satu, sama } \\
\text { sekali tidak ada } \\
\text { duanya }\end{array}$ & $\begin{array}{l}\text { Pada hakikatnya } \\
\text { Tuhan itu satu, } \\
\text { diberi nama } \\
\text { banyak, seperti: } \\
\text { Narayana, Siwa, } \\
\text { Mahadewa, Iswara, } \\
\text { dll. }\end{array}$ & $\begin{array}{l}\text { Nantram Puja Tri } \\
\text { Sandhya bait ke 2 }\end{array}$ \\
\hline $\begin{array}{l}\text { Ekam eva advityam } \\
\text { Brahman }\end{array}$ & $\begin{array}{l}\text { Hanya satu Tuhan } \\
\text { (Brahman), tidak } \\
\text { ada yang ke dua }\end{array}$ & $\begin{array}{l}\text { Hanya satu Tuhan } \\
\text { tidak ada duanya }\end{array}$ & $\begin{array}{l}\text { Chandogya } \\
\text { Upanisad }\end{array}$ \\
\hline $\begin{array}{l}\text { Bhineka Tunggal } \\
\text { Ika Tan hana } \\
\text { Dharma Mangrwa }\end{array}$ & $\begin{array}{l}\text { Berbeda-beda } \\
\text { tetapi tetap satu, } \\
\text { tiada kebenaran } \\
\text { mendua }\end{array}$ & $\begin{array}{l}\text { Hanya satu Tuhan, } \\
\text { namun kapan } \\
\text { kebenaran (Tuhan) } \\
\text { itu dapat dibagi dua }\end{array}$ & $\begin{array}{l}\text { Lontar Suta Soma, } \\
\text { karya } \\
\text { Tantular }\end{array}$ \\
\hline
\end{tabular}

Penjelasan tentang Konsepsi Keesaan Tuhan dalam berbagai sumber tersebut di atas, sebagai berikut :

Terkait pemahaman tentang Keesaan Tuhan sebagai mana diuraikan dalam tabel (1) di atas, menunjukkan Tuhan Yang Mahaesa dipahami secara berbeda-beda, secara parsial oleh umat Hindu, sangat tergantung pada tingkat pemahaman dan kemampuan manusia itu sendiri. Namun jika mengacu pada konsep tri kona, yaitu : utpati, sthiti dan pralina (lahir, hidup dan mati) adalah sesuatu yang sangat logis, yaitu sesuatu yang pernah lahir, pasti hidup (walaupun sesaat) pada akhirnya akan mati. Artinya, semua kehidupan pasti akan mengalami proses tersebut sebagai hukum kodrat alam semesta (Rta), semua yang ada di alam semesta ini tuntuk terhadapnya, tanpa terkecuali. Manusia menyadari akan keterbatasan dirinya dan memahami akan kemahakekuasaan Tuhan yang luar biasa (mahasempurna) yang serba tak terbatas, baik dalam proses penciptaan (utpati), pemeliharaan (sthiti) maupun pengembalian ke asalnya (pralina) terhadap segala sesuatu yang ada di alam semesta ini, sehingga manusia meyakini kemahakekuasaan Tuhan sebagai Tri Murti, yaitu sebagai pencipta Tuhan disebut Brahma, sebagai pemelihara disebut Wisnu dan sebagai pemralina disebut Siwa. Tri Murti adalah tiga perwujudan kemahakekuasaan Tuhan yang sesungguhnya tunggal (Esa) dengan pranawa "OM" yang kemudian diimplementasikan dengan pranawa aksara suci (symbol) : Ang (Brahma), Ung (Wisnu) dan Mang (Siwa) yang kemudian disandhikan kembali menjadi satu "OM" (tunggal). Dapat dipahami Tuhan yang satu diimplementasikan ke dalam tiga perwujudan (Tri Murti), namun sesungguhnya semua itu satu (Esa) adanya.

\section{Pemujaan Tri Murti pada Tataran Desa Adat}

Hasil keputusan Samuantiga di Desa Bedulu pada masa silam (awal abad 11 Masehi/tahun 1001 Masehi) melahirkan kesefakatan konsep ajaran Tri Murti oleh semua sekta yang hadir pada sidang/samua tersebut, dengan kesefakatan bersama pendirian Pura Kahyangan Tiga, yang terdiri dari : Pura Desa/Bale Agung, Pura Puseh dan Pura Dalem pada setiap desa pakraman/desa adat. Kahyangan Tiga adalah pura teritorial, mencakup pemujaan terhadap Tuhan/Ida Sanghyang Widhi Wasa dalam manifestasiNya sebagai pencipta (Brahma) dipuja di Pura Desa/Bale Agung, pemelihara (Wisnu) dipuja di Pura Puseh dan pemralina (Siwa) dipuja di Pura Dalem. Tiga esensial penting pemujaan yang di dalamnya telah terkandung konsep ajaran Tri Murti, yang kesemua dewa dipuja oleh umat Hindu terutama bagi umat yang berdomisili di wilayah wewidangan teitorial dalam lingkup desa pakraman/desa adat, sesuai yang ditunjuk pada data gambar, berikut : 


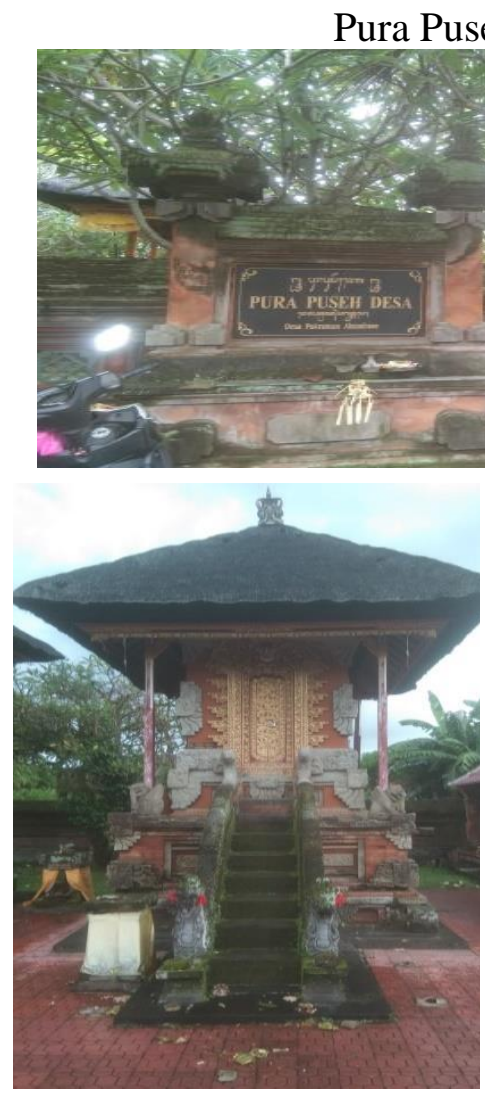

Gambar 01

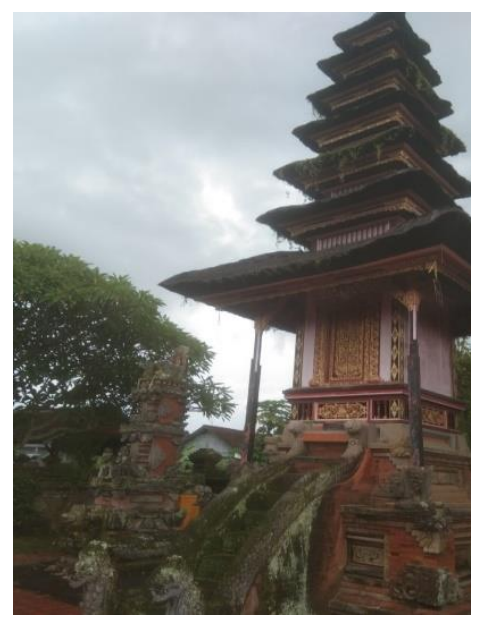

Gambar 02
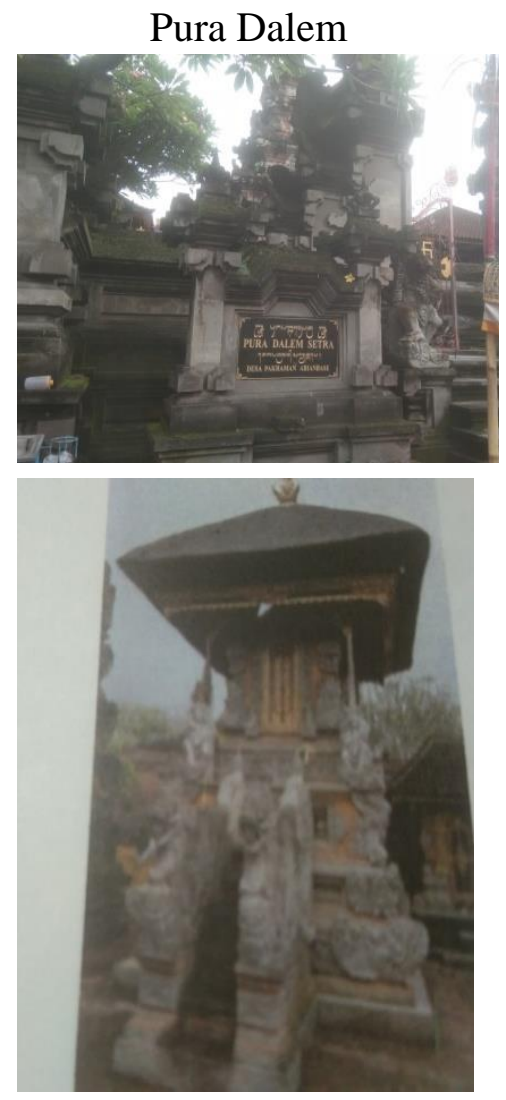

Gambar 03

Rincian penjelasan gambar Kahyangan Tiga akan diuraikan, sebagai berikut :

Kahyangan Tiga, adalah tiga pura teitorial dalam lingkup wilayah wewidangan desa pakraman/desa adat, selain adanya kahyangan desa. Data ini sebagai sampel penelitian difokuskan pada Desa Adat Abianbase Gianyar. Kondisi Kahyangan Tiga bervariasi antara satu desa pakraman/desa adat dengan desa pakraaman/desa adat lainnya. Edialnya yang dimaksud sebagai Kahyangan Tiga mencakup tiga buah pura, yaitu Pura Desa/Bale Agung, Pura Puseh dan Pura Dalem. Namun fakta (kenyataaan) di lapangan, tidak semuanya demikian. Kadangkala ada kecenderungan Pura Desa/Bale Agung digabung dengan Pura Puseh (berada dalam satu areal) yang di Desa Adat Abianbase Gianyar disebut Pura Puseh-Desa Abianbase, sebagaimana yang terdapat dalam sampel dan satu Pura Taulan dan Pura Beji (sebagai pura kahyangan desa). Di desa pakraaman/desa adat lainnya di Desa Adat Bona misalnya jumlah puranya lebih dari tiga buah, yaitu Pura Desa/Bale Agung, Pura Puseh dan Pura Dalem Setranya banyak (hingga 4 buah Pura Dalem).

Ciri-ciri Pura Desa/Bale Agung, yaitu adanya sebuah bangunan bale panjang (bale agung) yang bangunannya agak memanjang/melintang pada umumnya berlokasi di madya mandala (jaba tengah) dan palinggih intinya Gedong Desa sebagai tempat bersthananya Dewa Brahma (gambar 01). Pura Puseh dengan palinggih intinya Meru Tumpang Pitu sebagai tempat berstahanya Dewa Wisnu (gambar 02). Karena di Desa adat Abianbase kondisi Pura Desa/Bale Agung dan Puseh digabung, maka palingih inti Gedong Desa dan Meru Tumpang Pitu berada dalam satu areal di utama mandala (jeroan). Sedangkan Pura Dalem yang terkait dengan Kahyangan Tiga di Desa Pakraman Abianbase adalah Pura Dalem Setra yang terletak pada arah selatan dari desa pakraman/desa adat yang berdampingan dengan lokasi setra. Pura Dalem sebagai tempat pemujaan Dewa Siwa dengan ciri utamanya dekat kuburan dan palinggih intinya Gedong Dalem (gambar 03). 


\section{Pemujaan Tri Murti dalam Keluarga}

Pada tingkat keluarga, pemujaan Tri Murti diimplementasikan berbentuk palinggih Kamulan Rong Telu/Tiga pada setiap rumah, yaitu sebuah bangunan palinggih yang pada umumnya terletak pada arah terbit matahari (timur) menghadap ke barat, umumnya di daerah dataran Bali Selatan dengan style bebaturan yang pada bagian atasnya dibuat dari kayu beratap ijuk, alang-alang, genteng ataupun sirap dan kadang kala terbuat dari batu. Pada bagian atas terbagi atas tiga ruangan (rong) berjejer ke samping. Sedangkan di Daerah Tabanan dan Bali Utara sedikit bervariasi. Adapun jenis-jenis Kamulan Rong Telu/Tiga, sebagai mana tertera dalam data, berikut :

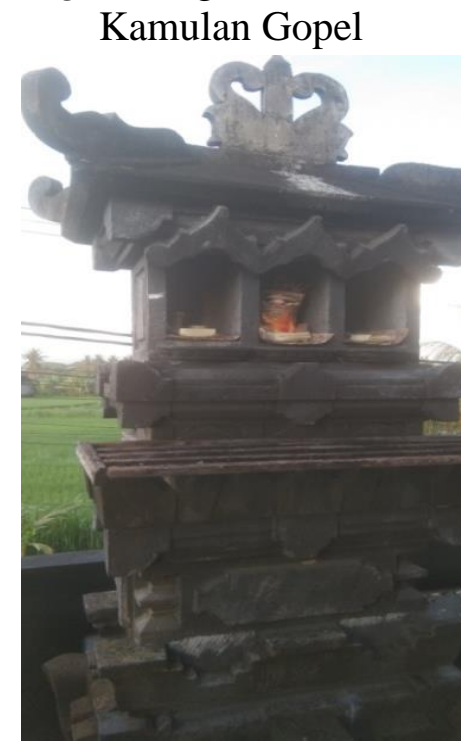

Gambar 04

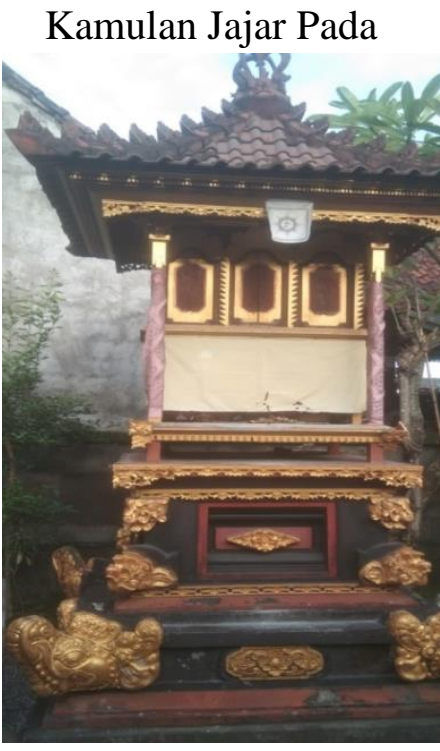

Gambar 05

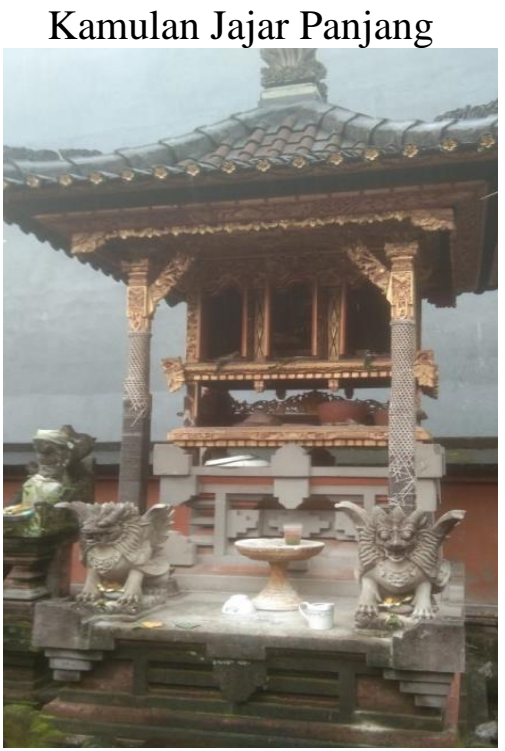

Gambar 06 berikut :

Rincian penjelasan gambar Kamulan Rong Telu/Tiga akan diuraikan, sebagai

Style Sanggah Kamulan dapat dibedakan menjadi tiga macam dengan tampilan yang sedikit berbeda, yaitu : 1) Kamulan Gopel, yaitu Sanggah Kamulan yang bagian atas dari bebaturan disusun langsung rong telu yang pada umumnya terbuat dari bahan kayu atau bisa juga dari batu padas atau yang sejenisnya (gambar 04); 2) Kamulan Jajar Pada, yaitu Sanggah Kamulan yang bagian atas dari bebaturan ditambahkan dua saka (tiang depan, sebagai penyangga rong telu) di mana panjang saka sama (sejajar atau jajar pada) dengan bebaturan badan sanggah (gambar 05); 3) Kamulan Jajar Panjang, yaitu Sanggah Kamulan yang bagian atas dari bebaturan ditambahkan dua saka (tiang depan, sebagai penyangga rong telu) yang panjang sakanya melebihi badan sanggah hingga ke bebaturan depan bawah (gambar 06).

Sejalan dengan efek (kognitif, afektif dan behavioral) yang terjadi setelah berlangsungnya "pesamuantiga" atau tryadic communication, maka untuk menganalisis data digunakan teori efek komunikasi massa (dependency theory). Dependency theory adalah teori ketergantungan. Dalam komunikasi massa, teori ini disebut "dependensi efek komunikasi massa". Kata efek dalam bahasa Inggris "effect" berarti akibat/hasil (Wojowasito \& Poerwadarminta, 1980). Efek yang dimaksud adalah akibat/hasil dari proses komunikasi. Efek adalah pengaruh yang ditimbulkan oleh adanya sebab/perbuatan, berupa akibat atau dampak yang ditimbulkannya (Partanto \& Barry, 1994). Efek mununjukkan adanya perubahan yang dapat diamati dan diukur penerima, disebabkan oleh adanya elemen-elemen dari proses komunikasi yang bisa diidentifikasi (Fiske, 2012, p. 50). Dengan demikian, yang dimaksud efek adalah implikasi, dampak, atau akibat yang ditimbulkannya sebagai akibat dari berlangsungnya proses komunikasi. Namun demikian, 
pada intinya (Senjaya, dkk, 2007, p. 5.28-5.29) merumuskan tiga efek yang dapat ditimbulkan media massa, yang terdiri dari : 1) Efek Kognitif, meliputi : a) menciptakan atau menghilangkan ambiguitas; b) Pembentukan sikap dan agenda-setting; c) Perluasan sistem keyakinan masyarakat dan d) Penegasan/penjelasan nilai-nilai; 2) Efek Afektif, meliputi : a) menciptakan ketakutan atau kecemasan; b) meningkatkan atau menurunkan dukungan moral; 3) Efek Behavioral, meliputi : a) mengaktifkan/menggerakkan atau meredakan; b) pembentukan isu tertentu atau penyelesaiannya; c) menjangkau atau menyediakan strategi untuk suatu aktivitas, d)menyebabkan perilaku dermawan (menyumbangkan uang).

Berdasarkan ketiga jenis efek media massa seperti tersebut di atas, dapat diidentifikasi tanda-tanda efek komunikasi massa (Rakhmat, 2007), adalah : Efek kognitif, bisa terjadi bila ada perubahan pada apa yang diketahui, dipahami, atau dipersepsi khalayak, yang berkaitan dengan transmisi pengetahuan, ketrampilan, kepercayaan ataupun informasi. Efek afektif, muncul apabila ada perubahan pada apa yang dirasakan, disenangi atau dibenci khalayak, yang berhubungan dengan emosi, sikap atau nilai. Sedangkan efek behavioral, merujuk pada prilaku nyata yang dapat diamati, berupa pola tindakan, kegiatan atau kebiasaan berprilaku. Untuk membedakan ketiga jenis efek komunikasi tersebut dapat diacu dengan mengajukan pertanyaan-pertanyaan berikut, yaitu : apakah efek dapat diketahui atau tidak, apakah efek dapat dirasakan atau tidak, dan apakah efek dapat merujuk prilaku nyata yang dapat diamati atau tidak. Jawaban atas pertanyaan tersebut akan lebih memudahkan pengklasifikasian efek, apakah hal tersebut termasuk dalam efek kognitif, afektif atau behavioral/konatif. Dalam kajian berikut karena keterbatasan waktu yang tersedia, pembahasan dibatasi lebih terfokus pada efek kognitif tryadic communication Pura Samuantiga saja, terutama yang berhubungan dengan konsep pengetahuan ajaran Tri Murti.

Tryadic communication adalah pertemuan segi tiga perwakilan antar tokoh-tokoh besar sampradaya/sekta keagamaan Hindu yang berlangsung di Bata Anyar telah terbukti melahirkan konsep pemikiran, berupa epek kognitif lahirnya konsep pemujaan Tri Murti dan lahirnya desa-desa pakraman/desa adat di Bali, sebagai suatu pengetahuan atau pemahaman penting bagi umat Hindu berlandaskan hasil Keputusan Samuantiga di masa lampau, yang telah disefakati bersama oleh para tokoh sampradaya/sekta keagamaan Hindu pada masa itu, serta mendapat dukungan penuh dari pihak pemerintahan (kerajaan Bedahulu) pada massa kejayaan kekuasaan maharaja Dharma Udayana yang dikuatkan dengan Keputusan Samuantiga dijadikan acuan dan wajib dilaksanakan oleh seluruh umat Hindu di Bali. Adapun hasil hasil Keputusan Samuantiga yang dimaksud, adalah sebagai berikut :

Pertama, paham Tri Murti dijadikan dasar keagamaan yang melingkupi semua sekta yang ada di Bali masa itu. Tri Mūrti adalah simbol dari keyakinan untuk memuja tiga dewa sebagai satu kesatuan, yaitu : Dewa Brahma, yang memiliki sifat sebagai pencipta alam semesta; Dewa Wisnu, yang memiliki sifat sebagai pemelihara alam semesta; dan Dewa Śiwa, yang memiliki sifat sebagai pralina atau memusnahkan alam semesta.

Kedua, dibentuk organisasi masyarakat desa yang disebut desa pakraman, dengan kahyangan tiga sebagai salah satu sendi dasarnya. Kahyangan tiga adalah tiga tempat suci (pura) yang harus ada dalam suatu desa pakraman, yaitu : (a) Pura Desa atau Pura Bale Agung, yakni tempat suci untuk memuliakan Dewa Brahmā; (b) Pura Puseh, yakni tempat suci untuk memuliakan Dewa Wisnu; (c) Pura Dalem, yakni tempat suci untuk memuliakan Dewa Śiwa.

Ketiga, dalam setiap rumah tangga didirikan sebuah pelinggih atau tempat pemujaan di rumah yang berbentuk rong telu (rong tiga). Fungsinya (dalam konteks 
kekinian) adalah untuk memuja dan memuliakan Sang Hyang Widhi Wasa (Tuhan) dan roh suci para leluhur (keluarga). Nama lain dari rong tiga adalah Kamulan yang terdapat dalam sanggah atau mrajan (pura keluarga). Jadi, kalau pada tingkat desa terdapat tempat pemujaan yang dinamakan kahyangan tiga, maka pada tingkat rumah tangga terdapat tempat pemujaan yang disebut pelinggih rong tiga.

Keempat, semua tanah pekarangan dan tanah yang terletak di desa pakraman/desa adat dan pura (kahyangan tiga) adalah milik desa dan pura.

Kelima, nama agama yang dianut oleh masyarakat Bali selanjutnya disebut sebagai Agama (Hindu) Śiwa-Budha (Gunawan, 2014, p. 84-85).

Pura Kahyangan Tiga adalah tempat suci umat Hindu sebagai media pemujaan Dewa Tri Murti, yaitu manifestasi Tuhan/Ida Sanghyang Widhi Wasa. Ketiga pura tersebut berkaitan erat dengan tugas dan fungsi Tuhan/Ida Sanghyang Widhi Wasa dalam melakukan proses penciptaan, pemeliharaan dan pemralina terhadap segala ciptaanNya. Pura Kahyangan Tiga sebagai media symbol pemujaan Tuhan/Ida Sanghyang Widhi Wasa (komuniaksi transcendental Hindu), yang terdiri dari : 1) Pura Desa/Bale Agung, sebagai tempat pemujaan Dewa Brahma yaitu manifestasi Tuhan/Ida Sanghyang Widhi Wasa sebagai pencipta; 2) Pura Puseh sebagai tempat pemujaan Dewa Wisnu, yaitu manifestasi Tuhan/Ida Sanghyang Widhi Wasa sebagai pemelihara; dan 3) Pura Dalem, sebagai tempat pemujaan Dewa Siwa manifestasi Tuhan/Ida Sanghyang Widhi Wasa sebagai pemralina.

Konsep Keesaan Tuhan yang yang mengacu pada sumber ajaran Veda, di samping juga krama desa adat berkewajiban melakukan pemujaan di Pura Kahyangan Desa yang berlokasi di sekitarnya selain Kahyangan Tiga. Sedangkan pada tingkat keluarga sebagai implementasi dari hasil Keputusan Samuantiga, maka didirikanlah Kamulan Rong Telu/Tiga yang sekaligus berfungsi sebagai tempat suci melakukan pemujaan Dewa Tri Murti, yaitu : Dewa Brahma, Wisnu dan Siwa yang mengacu pada konsep ajaran Veda "Ekam Sat Viprah Bahuda Vadanti" pada tataran pemahaman seecara teologis umat Hindu, yang mengacu pada konsep Keesaan Tuhan.

Analisis tersebut memperlihatkan Pura Kahyangan Tiga sebagai media pemersatu sampradaya/sekta keagamaan Hindu pada tataran desa adat/desa pakraman di Bali diwujudkan berbentuk simbol pemujaan Dewa Tri Murti sebagai manifestasi Tuhan/Ida Sanghyang Widhi Wasa berupa pendirian Pura Kahyangan Tiga, yang terdiri dari : Pura Desa/Bale Agung, Puseh dan Dalem. Sedangkan pada tingkat keluarga Sanggah Kamulan Rong Telu sebagai media pemersatu keluarga. Untuk itu, pada kajian berikut akan dibahas mengapa terjadi efek tryadic communication Pura Samuantiga pada tingkat penahaman masyarakat Hindu secara teologis terhadap sumber ajaran Veda di Bali, pemahaman umat Hindu pada tataran desa pakraman/desa adat dan pemahaman pada lingkup keluarga.

\section{a. Mengapa terjadi Efek Tryadic Communication Pura Samuantiga pada Pemahaman Teologis Konsepsi Keesaan Tuhan menurut Weda yang Diimplementasikan sebagai Tri Murti bagi Masyarakat Hindu di Bali ?}

Manusia pertama yang diciptakan Tuhan/Ida Sanghyang Widhi Wasa menurut konsep ajaran Hindu adalah "manu" (berarti ia yang memiliki manah atau pikiran) melalui proses yang menjadikan dirinya sendiri (swayambhu manu), dari perkataan manu berubah menjadi manusia, yaitu makhluk yang mempunyai sifat berkemampuan berfikir. Dengan kelebihan pikiran, rasa dan karsa yang dimiliki, manusia mampu menciptakan dan mengubah alam semesta menjadi sesuatu yang bermanfaat atau bermakna bagi kehidupannya. Tri Murti adalah tiga perwujudan utama Tuhan atau manifestasi Tuhan sebagai Brahma, Wisnu dan Siwa. Brahma mengandung arti : tumbuh, berkembang, berevolusi, yang bertambah besar, yang meluap dari diriNya dan sejenisnya (Monier, 1993). CiptaanNya muncul dari dirinya, seperti halnya Weda yang muncul dari nafasNya. Kamahakekuasaan Brahma didukung oleh saktinya Dewi Saraswati, yaitu dewi 
pengetahuan dan kebijaksanaan yang memberikan inspirasi untuk kebajikan umat manusia. Dengan demikian, Brahma adalah dewa pencipta seluruh alam semesta beserta isinya (Noorsena \& Titib, 2001). Wisnu adalah manifestasi Tuhan dalam memlihara jagat raya dan segala isinya. Wisnu adalah Ia yang menghidupkan segalanya. Perkataan Visnu berarti : pekerja, yang meresapi segalanya dan sejenisnya (Monier, 1993). Kekuatan Visnu dalam memelihara alam semesta beserta segala isinya didukung oleh saktinya dewi Sri dan Laksmi. Demikian juga halnya Siva adalah Tuhan Yang Mahaesa dalam manifestanya sebagai pelebur alam semesta dengan segala isinya (Noorsena \& Titib, 2001). Perkataan Siva berarti : yang memberikan keberuntungan (kerahayuan), yang baik hati, ramah, suka memaafkan, menyenangkan, memberi banyak harapan, yang tenang, membahagiakan dan sejenisnya (Monier, 1993).

Berdasarkan kutipan data "hasil Keputusan Samuantiga" pada point kelima (terakhir) disebutkan bahwa nama agama yang dianut masyarakat Hindu di Bali adalah Agama Siwa-Budha, sejalan dengan temuan data sesanti ke empat (pada tabel 1) di atas yang menyebutkan "Bhineka Tunggal Ika Tan hana Dharma Mangrwa". Kebenaran yang tertinggi dari kedua sekta keagamaan Śaiva-Baudha akhirnya bertemu pada tingkatan yang tertinggi. Kebenaran adalah satu, namun cara mencapainya berbeda (Mantra, 1958, p. 3637), sebagaimana dikatakan Mpu Tantular dalam lontar Sutasoma (lembar 24), sebagai berikut :

Hyang Budha tanpahi Siva raja dewa;

rvanekadhatu vinuvus wara-budha visva;

Bhinneki rakwa ring apan kena parwa nossen;

Mangka jinatva lawan Śiwatātwa tunggal;

Bhineka tunggal ika tan hana dharma mangrwa.

Terjemahannya : Sesungguhnya Budha tidak berbeda dengan Śiva sebagai penguasa tertinggi. Tuhan itu dikatakan dua, disebut Budha dan Śiva. Berbeda itu konon, namun kapan dibagi dua, demikianlah kebenaran ajaran Budha dan Śiva yang pada hakikatnya adalah satu, tetapi tetap tunggal itu, tidak ada Tuhan yang kedua. Konsep di atas menunjukkan "bhineka tunggal ika" yang dijadikan slogan lambang Negara Kesatuan Republik Indonesia (NKRI) yang tercengkram oleh kedua kaki burung "Garuda Pancasila" yang berasal dari perkataan "bhina ika tunggal ika" sesuai lontar Sutasoma, yang mengandung makna berbeda itu (bhina ika), namun satu itu (tunggal ika). Maksudnya berbeda-beda, tetapi tetap satu jua. Sesanti itu sangat cocok dengan kondisi masyarakat Indonesia yang pluralistik/majemuk, yang terdiri dari beranekaragam adat-istiadat, budaya, bahasa, dan agama (termasuk sekta keagamaan Hindu) yang pernah berkembang pesat pada masa lampau di Bali.

Ajaran Śiva-Budha di Bali sudah luluh dan menyatu, telah mengalami proses sinkretisasi. Sinkretisasi diartikan sebagai proses penggabungan pihak-pihak, prinsipprinsip, kebudayaan-kebudayaan yang saling bertentangan sehingga paling tidak luluh menjadi satu (Sujamto, 2000). Sinkritisasi sebagai penggabungan atau penyatuan dari dua aliran agama atau aliran kepercayaan (Salir, 1995). Sinkretisasi Siva-Budha dimaksudnya sebagai penggabungan, percampuran, perpaduan sebagai akibat persinggungan atau kontak budaya dengan menenggelamkan berbagai perbedaan dan menghasilkan kesatuan di antara berbagai sekta atau aliran falsafah agama dan kepercayaan Siva-Budha di Bali (Nida, 2007, p. 20). Paham "Śaiva dan Baudha" itu diidentifikasi hanya mengenai prinsip kebenaran tertinggi beserta segala manifestasinya, tetapi dalam pelaksanaan peribadatan keduanya masih tetap terpisah. Konsep penyatuan Śaiva dan Baudha ternyata telah terjadi sejak kedua agama tersebut bersama-sama berada di Jawa Timur (abad VIII Masehi). Di Bali, perpaduan dari kedua aliran (paham keagamaan) tersebut menyatu, ditambah pengaruh unsur-unsur lainnya yang juga datang ke Bali, seperti ajaran Bairawa dan 
Tantrayana. Ditambah lagi unsur-unsur tradisional (local genius) sebagai warisan leluhur/nenek moyang, seperti halnya kepercayaan terhadap "gunung" sebagai tempat pemujaan roh nenek moyang, kepercayaan totemisme yang menganggap binatang atau tumbuh-tumbuhan mempunyai kekuatan magis. Konsep Siwa Siddhanta di Bali berkembang dengan formula "eka twam, aneka twam, swalaksana bhatara", yang artinya : Tuhan itu satu, namun tidak satu juga dan kembali menjadi satu (Informan 8 : Sukada, 71 tahun). Pernyataan tersebut merupakan penguatan bahwa Tuhan itu satu dapat diberi nama banyak, namun pada hakikatnya tetap satu jua adanya. Dengan demikian, mengapa perbedaan nama Tuhan (aspek ideologis) dalam berbagai keyakinan penganut sekta keagamaan mesti dipermasalahkan atau dipertentangkan ? Pada tingkat pemahaman pemikiran teologis konsep Keesaan Tuhan menurut sumber ajaran Veda. Secara filofofis, idealnya bahwa hidup dapat menciptakan sesuatu yang patut diciptakan (utpati). Hidup untuk memelihara serta melindungi sesuatu yang sepatutnya dilindungi (sthiti). Demikian juga halnya hidup adalah meniadakan sesuatu yanag sepatutnya ditiadakan atau dimusnahkan (pralina). Tri Kona inilah sebagai dasar pengendalian dinamika hidup agar hidup senantiasa berproses secara positif menuju pada peningkatan kualitas dalam mewujudkan tujuan hidup di dunia sekala, untuk mencapai tujuan dharma, artha dan kama dan pencapaian moksa di dunia niskala (Wiana, 2007, p. 7).

Mengapa lahir konsep ajaran Tri Murti, padahal sekta yang bersidang yang mewakili sekian banyak sekta besar saat itu di Bali, yaitu : Sekta Siwa Siddhanta, Budha Mahayana dan Sadsekta Bali Aga. Sekta Siwa Siddhanta adalah sekta yang penganutnya sangat besar di Bali memang wajar mewakili kelompok sekta dari ajaran Siwa, sedangkan Budha Mahayana adalah aliran sekta keagamaan Hindu (yang bercenderungan) mewakili sekta Waisnawa (penganut ajaran Wisnu), sedangkan Sadsekta Bali Aga adalah kelompok sekta kecil namun keberadaannya tidak bisa diabaikan begitu saja dan memang tidak terlihat dengan jelas mewakili sekta yang tergolong Brahmaisme (penganut aliran Brahma). Untuk mencegah terjadinya konflik atau paling tidak untuk mengelola kemungkinan berbagai konflik yang muncul dari pluralitas agama, maka Mpu Kuturan mengajukan usul dengan argumentasi logis yang dapat diterima oleh semua kalangan peserta sidang, sehingga menjadi kesefakatan/komitmen bersama lahirnya konsep ajaran Tri Murti berupa hasil Keputusan Samuantiga (Raka, 2010). Mpu Kuturan mampu mempersuasif audience yang hadir ketika "samua", beliau dipandang sebagai sosok yang berhasil mengintegrasikan berbagai kepentingan golongan atau sekta-sekta di Bali, sehinga masing-masing sekta menjungjung kepentingan yang sarat dengan potensi konflik dapat dipersatukan (Goris, 1974). Walaupun demikian, kepentingan sekta-sekta yang kecil juga terakses atau terakomodir, diberikan keleluasaan, masih mendapat ruang dan waktu (Informan 5 : Susana, 57 tahun). Dengan demikian, maka setelah itu keadaan masyarakat menjadi aman dan nyaman, tidak lagi ada permasalahan sekta yang muncul di permukaan.

Konsep Tri Murti yang intinya mengajarkan bahwa Tuhan memiliki tiga kemahakuasaan yakni sebagai pencipta (utpati), pemelihara (sthiti) dan pengembalian ke asalnya (pralina) yang termanifestasikan sebagai Dewa Brahma, Wisnu dan Siwa, diikrarkan pada suatu lokasi yang kini diberi nama Pura Samuantiga (Ardana, 1981). Dengan keahlian bidang agama yang dikuasai Mpu Kuturan, sehingga beliau diberi kehormatan menduduki posisi sentral sebagai Senapati Kuturan, yakni sebuah jabatan yang membidangi keagamaan. Keberhasilan beliau di bidang keagamaan berawal dengan terealisasinya deklarasi konsep Tri Murti yang dihadiri oleh sekta-sekta yang ada di Bali, yang berlokasi di Pura Samuantiga Bedulu Gianyar, yang diwujudnyatakan dalam bentuk Pura Kahyangan Tiga pada setiap desa pakraman/desa adat, yang kini keberadaannya membumi di seluruh pelosok pulau Bali (Raka, 2010). 


\section{b. Mengapa terjadi efek Tryadic Communication Pura Samuantiga Pemujaan Tri Murti pada Tataran Desa Adat ?}

Pemahaman umat Hindu selama ini, Pura Samuantiga sebagai cikal bakal atau awal berdirinya Pura Kahyangan Tiga pada setiap desa adat/desa pakraman dan pendirian desa adat/desa pakraman di seluruh Bali. Pendirian Pura Samuantiga menggambarkan peristiwa penting (samua/rapat besar) yang pernah terjadi sebagai tonggak sejarah komunikasi Hindu di Bali, yang oleh masyarakat setempat menyebut komunikasi Samuantiga. Oleh karena itu, Pura Samuantiga adalah pura kawitan Kahyangan Tiga sebagai pusat pemujaan Tri Murti di Bali (Wirta, 2019). Mpu Kuturan mengikrarkan konsep yang diwujudnyatakan dalam bentuk bangunan suci Kahyangan Tiga (Raka, 2010). Pada tataran desa adat/desa pakraman, Kahyangan Tiga sebagai media pemersatu sekta keagamaan Hindu pada tingkat desa pakrman/desa adat. Berdasarkan temuan data (subbab 4.1.2) seperti yang telah dipaparkan di atas, terdapat sejumlah alasan pendirian Kahyangan Tiga bagi umat Hindu di Bali sebagai symbol pemujaan Tri Murti pada tataran desa pakraman/desa adat. Semua yang pernah hidup tanpa terkecuali mengikuti proses hukum alam (Rta) sebagai hukum kodrat yang telah ditentukan Tuhan. Yang pernah lahir pasti akan hidup (sekalipun sesaat) dan pada akhirnya akan mati. Tidak ada sesuatu yang pernah lahir tidak akan mati, semuanya pasti berproses mengikuti hukum alam semesta, yaitu : lahir, menjadi bayi, kanak-kanak, tumbuh dewasa, tua dan pada akhirnya pasti akan mati. Tiada yang kekal di dunia ini, kecuali Tuhan/Ida Sanghyang Widhi Wasa. Proses yang mesti dilalui : lahir, hidup, mati disebut tri kona (informan 2 : Weca, 60 tahun).

Setiap ciptaan, akan terjadi proses kehidupan dan pada akhirnya mengalami kematian. Bagi yang lahir, kematian adalah pasti dan bagi yang mati kelahiran tentu. Konsep Tri Kona (lahir, hidup dan mati) inilah yang menjadi alasan mendasar diterimanya usul yang diajukan/ditawarkan Mpu Kuturan berupa konsep ajaran Tri Murti pada saat sidang berlangsung di Bata Anyar (informan 6 : Mangku Dalem Kesian, 69 tahun). Manusia sebagai salah satu makhluk utama ciptaan Tuhan tidak terlepas dari ketiga siklus hukum alam semesta yang sering dinamai rta. Dengan konsep Tri Kona, semua kepentingan sekta terakomodir. Dimana ada hidup kematian pasti, karena semua yang hidup hanya menunggu proses menuju kematian (informan 5 : Susana, 57 tahun). Tuhan saat penciptaan dalam manifestasiNya sebagai Dewa Brahma disimbolkan dengan pendirian Pura Desa/Bale Agung, saat pemeliharaan Tuhan/Ida Sanghyang Widhi Wasa bermanifestasi sebagai Dewa Wisnu disimbolkan dengan pendirian Pura Puseh dan saat mempralina ciptaanNya Ida Sanghyang Widhi Wasa bermanifestasiNya sebagai Dewa Siwa disimbolkan dengan pendirian Pura Dalem (informan 3: Mangku Ageng Samuantiga, 60 tahun). Berdasarkan pandangan beberapa informan seperti tersebut di atas, menunjukkan konsep Tri Kona (lahir, hidup dan mati) yang diimplementasikan menjadi Tri Murti yang kemudian direalisasikan dengan symbol pendirian tempat suci Kahyangan Tiga (Pura Desa/Bale Agung, Puseh dan Dalem) menjadi suatu hal yang sangat penting dipahami oleh semua sekta keagamaan Hindu di Bali. Pemanfaatan Kahyangan Tiga sebagai media pemujaan Tri Murti sangat terkait dengan upaya menjaga keseimbangan unsur tri guna (tiga sifat) dalam diri manusia.

Pemujaan Tuhan sebagai Dewa Wisnu di Pura Puseh sebagai symbol untuk menguatkan guna sattwam. Memuja Tuhan sebagai Dewa Brahma di Pura Desa/Bale Agung untuk mengendalikan guna rajas agar tetap aktif ke arah yang positif. Sedangkan memuja Tuhan sebagai Dewa Siwa untuk dapat mengendalikan guna tamas agar jangan berakibat negatif. Demikian juga halnya pemujaan Tuhan sebagai Tri Murti untuk memohon kepada Tuhan agar umat tertuntun untuk menyeimbangkan dinamika hidupnya berdasarkan Tri Kona (Wiana, 2007). Dengan demikian, memuja Tuhan di Pura Kahyangan Tiga mengandung makna membangun keseimbangan guna sattwam, rajas dan 
tamas. Jika guna sattwam dan rajas sama-sama kuat menopang alam pikiran (citta), maka guna sattwam mendorong orang berbuat baik, sedangkan guna rajas mewujudkan niat baik itu, maka sang atmanpun mencapai tujuan secara niskala.

Uraian tersebut menunjukkan bahwa Pura Kahyangan Tiga, yang terdiri dari : Pura Desa/Bale Agung, Puseh dan Dalem sebagai media pemersatu sampradaya/sekta keagamaan Hindu pada tataran desa adat/desa pakraman di Bali diwujudnyatakan berbentuk simbol pemujaan Dewa Tri Murti. Dengan demikian, masyarakat Hindu tidak perlu lagi mempermasalahkan perbedaan sekta dalam kehidupan sehari-hari di masyarakat, karena semua dewa (Brahma, Wisnu dan Siwa) dipuja oleh umat Hindu di Bali, tanpa terkecuali. Belakangan, banyaknya sampradaya asing yaitu aliran/sekta keagamaan Hindu yang berasal dari India berkembang pesat di Bali kadangkala membingungkan masyarakat/umat Hindu, sebagai salah satu phenomena menarik yang muncul belakangan ini di Bali. Ada berkecenderungan sampradaya hanya bernaung di bawah PHDI sebagai lembaga/majelis tertinggi umat Hindu, namun dalam mengimplementasikan ajarannya dalam praktek hidup keseharian di masyarakat, ada berkecenderungan pengikut-pengikutnya tidak mau menyesuaikan diri dengan konsep dresta adat Bali, sehingga berimplikasi menimbulkan kekacauan sosial keagamaan Hindu dalam kehidupan masyarakat pada desa pakraman/desa adat di Bali. Pura Kahyangan Tiga sebagai media mempersatukan warga masyarakat yang berbeda kepentingan secara teritorial (Raka, 2010). Dengan demikian, Kahyangan Tiga (Pura Desa/Bale Agung, Puseh dan Dalem) meliki peran yang sangat penting yaitu sebagai media prmersatu umat Hindu dalam tataran desa pakraman/desa adat di Bali

\section{c. Mengapa terjadi efek Tryadic Communication Pura Samuantiga dalam Lingkup Keluarga?}

Fakta realitas yang dapat dijadikan bukti berupa bangunan suci yang merujuk pada konsep ajaran Tri Murti selain Kahyangan Tiga adalah Sanggah Kamulan Rong Tiga/Telu pada tingkat keluarga, dan bahkan kemudian berkembang ke tingkat yang lebih luas namun masih berada dalam lingkup keluarga besar merupakan gabungan beberapa keluarga batih berupa merajan agung/sanggah gede yang secara tidak disadari telah mengikat tali persaudaraan dalam keluarga (Raka, 2010). Pada tingkat keluarga merupakan tingkat yang paling bawah sebagai sumber atau akar kekuatan, Dewa Tri Murti yaitu Dewa Brahma, Wisnu dan Siwa (sebagai pencipta, pemelihara dan pemralina) alam macrocosmos/bhuana agung dengan unsur kekuatan roh leluhur, yaitu ibunta, bapanta dan raganta sebagai unsur pencipta, pemelihara dan pemralina alam microcosmos/bhuana alit pada Sanggah Kamulan Rong Telu/Tiga. Sanggah Kamulan Rong Telu/Tiga sebagai media pemujaan Tri Murti, yaitu Dewa Brahma, Wisnu dan Siwa. Brahma pada rong sebelah selatan dengan warna wastranya merah, Wisnu pada rong sebelah utara dengan atribut warna wastranya hitam dan Siwa di tengah sebagai pusatnya dengan warna putih (informan 9 : Mangku Cemeng, 70 tahun). Sanggah Kamulan Rong Telu/Tiga selain sebagai media pemujaan Tri Murti juga sebagai perpaduan pemujaan roh leluhur yang sudah sidhadewata (informan 6 : Mangku Dalem Kesian, 69 tahun). Maksudnya roh leluhur yang sudah sidhadewata (melalui upacara nyekah, ngroras atau atma wedana) disthanakan juga di Sanggah Kamulan Rong Telu/Tiga, dengan posisi bapanta di tengen (kanan), ibunta di kiwa (kiri) dan raganta ring madya/tengah. Oleh karena itu, Palinggih Ibu/Palinggih Dewa Hyang Rong Dua (Purusa-Pradhana) tidak perlu lagi dibangun di merajan, sebab palinggih tersebut sudah tersedia pada pura tingkat keluarga yang lebih luas, yaitu di Pura Panti maupun Paibon.

Dengan demikian jelas menunjukkan, bahwa pada Kamulan Rong Tengah bersthana Bhatara Hyang Guru, yang secara horizontal (garis atas-bawah) Tuhan sebagai 
Parama Siwa, Sada Siwa dan Siwātma, dengan mantram pemujaan "Gurustava" (Mantramanjari 3), sebagai berikut : "Om Gurur Brahma, Gurur Wisnu, Gurur Dewa Maheswara, gurur saksat Param Brahma, tasmai srigurawe namah" (Ya Tuhan Engkau berwujud sebagai Tri Murti Guru, Engkau adalah Guru tertinggi dan Penguasa Agung, Tuhan adalah guru sejati yang mahatinggi, KepadaMulah hambaMu memuja) dan juga mantram pemujaan Tuhan sebagai Tri Murti secara vertical (garis mendatar) di Sanggah Kamulan (Stuti \& Stawa 152.1), sebagai berikut : "Om Brahma Wisnu Iswara dewan, Tri purusa suddhatmakam, Tri Dewa Tri Murti lokam, sarwa wighna winasanam" (Hyang Widhi dalam wujudMu sebagai Brahma, Wisnu, Iswara, Dewa Tri Purusa mahasuci, Tri dewa adalah Tri Murti, Semogalah hamba terbebas dari segala bencana). Dengan melihat Sanggah Kamulan Rong Telu/Tiga pada merajan dalam lingkup keluarga menyadarkan kita akan satu hakikat, bahwa kelak nanti setelah meninggal kita akan menyatu dan bersthana bersama-sama yang akan dipuja oleh perti sentana (keturunannya kelak) dalam satu tempat pemujaan, yaitu Sanggah Kamulan. Oleh karena itu, selama hidup permasalahan apapun yang pernah terjadi antarkeluarga, pada akhirnya kita akan bersamasama menyatu dan malingih pada Sanggah Kamulan (vasudaiva kutumbhakam). Dengan demikian, dapat dikatakan bahwa Kamulan Rong Telu/Tiga berfungsi sebagai media pemersatu keluarga, baik dalam keluarga batih maupun tingkat keluarga yang lebih luas dalam lingkup keluarga besar (warga, clan atau soroh).

\section{Kesimpulan}

Adapun temuan dalam penelitian ini bahwa nama "Pura Kahyangan Tiga" tidak menggambarkan jumlah pura yang sesuai yang seharusnya berjumlah tiga dalam setiap desa pakraman/desa adat, namun temuan data di lapangan (faktanya) berbeda, bisa saja satu desa pakraman/desa adat memiliki dua buah pura (jika Pura Desa/Bale Agung dan Pura Puseh digabung dalam satu areal) dan bahkan jumlah Pura Kahyangan Tiga bisa lebih dari tiga buah (bila Pura Dalem Setranya lebih dari satu) seperti yang terdapat di Desa Adat Bona Gianyar. Oleh karena itu perlu ditinjau kembali, nama Pura Kahyangan Tiga tidak sesuai dengan konsep yang dimaksud.

Berdasarkan uraian di atas, dapat ditarik beberapa kesimpulan, yaitu :

1. Tryadic communications adalah komunikasi segi tiga (samuan tiga) yang dalam implementasinya telah menimbulkan efek pamujaan Tri Murti di Bali, baik pada tingkat keluarga, desa pakraman/desa adat maupun secara lebih luas pada pura Sad Khyangan bagi seluruh masyarakat Hindu di Bali.

2. Efek tryadic communications Pura Samuantiga pada tataran desa pakraman/desa adat dibangun Pura Kahyangan Tiga, yang terdiri dari : Pura Desa/Bale Agung sebagai tempat pemujaan Dewa Brahma, Pura Puseh sebagai tempat pemujaan Dewa Wisnu dan Pura Dalem sebagai tempat pemujaan Dewa Siwa, sekaligus sebagai media pemersatu seluruh umat Hindu pada wilayah/wewidangan teritorial desa pakraman/desa adat.

3. Efek tryadic communications Pura Samuantiga pada lingkup keluarga dibangun Palinggih Kamulan Rong Telu/Tiga, sebagai media pemujaan Tri Murti dan roh leluhur yang sudah siddhadewata, sekaligus sebagai media pemersatu dalam lingkup keluarga.

Sedangkan saran terkait kontribusi dan keterbatasan dalam penelitian ini, adalah :

1. Penelitian ini berkontribusi memberi sumbangan untuk menambah wawasan pemahaman umat Hindu terhadap konsep Ajaran Tri Murti, baik pada tingkat desa pakraman/desa adat, maupun tingkat keluarga di Bali. 
2. Adapun keterbatasan dalam penelitian ini hanya memfokuskan kajian pada efek kognitif triadic communication Pura Samuantiga, sedangkan efek afektif dan behavioral masih perlu dikaji lebih lanjut bagi peneliti selanjutnya.

\section{Daftar Pustaka}

Ardana, I. G. (1981). Sejarah Perkembangan Hinduisme di Bali. Denpasar.

Dwiyanti, N. K. (2014). Pura Puseh di Desa Pakraman Manuaba, Tegallalang Gianyar Bali (Tinjauan Sejarah, Fungsi Pura dan Potensinya sebagai Pewarisan Nilai dalam Pembelajaran IPS Tingkat SMP Berdasarkan Kurikulum 2013. Singaraja: Jurusan Pendidikan Sejarah, Universitas Pendidikan Ganesha.

Fiske, J. (2012). Pengantar Ilmu Komunikasi. Jakarta: Rajawali Press.

Kamus Bali-Indonesia Beraksara Bali dan Latin. (2013). Denpasar : Badan Pembina Bahasa, Aksara dan Sastra Bali Provinsi Bali.

Kamus Bali-Indonesia. (1996). Denpasar: Tim Penyusun.

Goris, R. (1974). Sekte-sekte di Bali. Jakarta: Bhratara.

Gunawan, D. H. (2014). Perubahan Sosial di Pedesaan Bali, Dualitas, Kebangkitan Adat dan Demokrasi Lokal. Serpong: CV. Marjin Kiri.

Mahastuti, N. M., Utami, N. W., \& Wijatmaja, A. B. (2019). Manajemen Konservasi di Pariwisata Pura Desa dan Puseh, Desa Pakraman Batuan, Kecamatan Sukawati Gianyar. Prosiding Seminar Nasional Desain dan Arsitektur (Senada), Vol.2, Pebruari 2019 (pp. 483-489). Gianyar: Universitas Udaayana, Sekolah Tinggi Desain Bali dan Universitas Dwijendra.

Mantra, I. (1958). Pengertian Siwa-Buddha dalam Sejarah Indonesia. Denpasar: Institut Hindu Dharma Denpasar.

Miles, M. B., \& Hubermann, A. (1992). Analisis Data Kwalitatif. Jakarta: 41 Press.

Monier, S. W. (1993). Sanskrit-English Dictionry. New Delhi: Motilal Banarsidass.

Nida, D. (2007). Sinkretisasi Siwa-Buddha di Bali, Kajian Historis Sosiologis. Denpasar: Pustaka Bali Post.

Noorsena, B., \& Titib, I. M. (2001). Konsep Ketuhanan dalam Perspektif Hindu-Kristen, Makalah Dialog Agama, Mahasanti Puja di Gedung Wanita "Santi Graha". Denpasar: Institute for Syriac Christian Studies.

Oka Astawa, dkk. A. (2006). Pura Samuantiga Bedulu Gianyar. Gianyar: Pemerintah Kabupaten Gianyar dan Paruman Pura Samuantiga, Bedulu Gianyar.

Partanto, P. A., \& Barry, M. D. (1994). Kamus Ilmiah Populer. Surabaya: Arkola.

Prami, A. I. (tt.). Meningkatnya Intensitas Konflik Desa Pakraman di Bali. Denpasar: Prodi Sosiologi Fakultas ilmu Sosial Politik Universitas Udayana.

Profil Pura Kahyangan Jagat di Bali. (2012). Denpasar : Lembaga Penelitian dan Pengabdian kepada Masyarakat Universitas Udayana.

Raka, A. G. (2010). Seribu Tahun Mpu Kuturan di Bali. Gianyar: Dinas Kebudayaan Kabupaten Gianyar.

Rakhmat, J. (2007). Psikologi Komunikasi. Bandung: PT. Remaja Rosdakarya.

Salir, P. (1995). Kamus Bahasa Indonesia Kontemporer.

Senjaya, S. D. (2007). Teori Komunikasi. Jakarta: Universitas Terbuka.

Setiada, N. K. (2003). Desa Adat Legian ditinjau dari Pola Desa Tradisional Bali. Jurnal Permukiman Natah,Vol.1, No.2,Juni 2003, 59-64.

Soebandi, J. M. (2003). Babad Pasek, Maha Gotra Pasek Sanak Sapta Rsi, edisi Lengkap disertai Keturunan Warga Pasek. Denpasar: PT. Pustaka Manikgeni.

Suadnyana, I. B. (tt.). Desa Pakraman sebagai Lembaga Adat dan Lembaga Agama bagi Kehidupan Masyarakat Hindu di Bali. Singaraja: STAHN Mpu Kururan Singaraja. 
Suarmini, N. W. (2011). Peranan Desa Pakraman dalam Memperkuat Ketahanan Sosial Budaya melalui Konsep Ajaran Tri Hita Karana. Jhs jurnal Sosial Humaniora, Vol. 4, No.1, Juni 2011, 1-12.

Sudana, A. O. (2011). Implementasi struktur Tree pada Rancang Bangun Sistem Penelusuran sejarah Pura Kawitan dan Kahyangan Jagat Berbasis Web. lontar Komputer,Vol. 2, No. 1 Juni 2021, 69-82.

Sujamto. (2000). Reorientasi dan revitalisasi Pandangan Hidup Jawa.

Susanta, I., Laskara, I., Swanendri, N., \& Suartika, G. (2018). Penataan Terintegrasi Pura Dalem Desa Gunaksa, Kecamatan Dawan, Kabupaten Klungkung. Buletin Udayana Mengabdi, Vol.17, No.4, oktober 2018, 135-140.

Wiana, I. K. (2007). Sembahyang Memuja Tuhan dengan Sembilan Bentuk Bhakti. Denpasar: Panakom.

Wirta, I. W. (2019). Pura Samuantiga : Perspektif Komunikasi Hindu (Disertasi). Denpasar: Program Pascasarjana Institut Hindu Dharma Negeri Denpasar.

Wojowasito, S., \& Poerwadarminta. (1980). Kamus Lengkap Inggris-Indonesia, Indonesia Inggris dengan Ejaan Yang Disempurnakan. Bandung : Hasta.

\section{Daftar Informan:}

Informan 1 : Drs. Anak Agung Gede Rai, 77 tahun, laki-laki, Manggala Paruman Pura Samuantiga, alamat : Banjar Batu Lumbang, Desa Bedulu, Kecamatan Blahbatuh, Kabupaten Gianyar.

Informan 2 : Drs. I Wayan Weca, M.Ag, 80 tahun, laki-laki, Ketua Umum/Panglingsir Parekan Pura Samuantiga, alamat: Banjar Tengah, Desa Bedulu, Kecamatan Blahbatuh, Kabupaten Gianyar.

Informan 3 : Gusti Mangku Ageng Samuantiga, 60 tahun, laki-laki, Pemangku, Alamat : Banjar Pekandelan, Desa Bedulu, Kecamatan Blahbatuh, Kabupaten Gianyar.

Informan 4 : Drs. I Wayan Patera, M.Hum, 69 tahun, laki-laki, Tokoh masyarakat Bedulu, Alamat: Banjar Margabingung, Desa Bedulu, Kecamatan Blahbatuh, Kabupaten Gianyar. Informan 5 : I Gusti Agus Susana, 57 tahun, laki-laki, Tokoh masyarakat Bona, Alamat : Banjar Bona Kanginan, Desa Bona, Kecamatan Blahbatuh, Kabupaten Gianyar.

Informan 6 : Mangku Dalem Kesian, 69 tahun, laki-laki, Pemangku, Alamat : Banjar Kesian, Desa Lebih, Kecamatan Gianyar, Kabupaten Gianyar.

Informan 7 : Mangku Puseh Abianbase, 67 tahun, laki-laki, Pemangku, Alamat: Banjar Kaja Kauh, Desa Abianbase, Kecamatan Gianyar, Kabupaten Gianyar.

Informan 8 : Drs. I Nyoman Sukada, 71 tahun, laki-laki, Tokoh Masyarakat Hindu, Alamat : Banjar Denkayu Kelod, Desa Werdhi Bhuwana, Kecamatan Mengwi, Kabupaten Badung.

Informan 9 : Mangku Cemeng, 70 tahun, laki-laki, Pemangku, Alamat : Banjar Lebih Beten Kelod, Desa Lebih, Kecamatan Gianyar, Kabupaten Gianyar). 